\title{
THE EFFECT OF RELIGIOSITY AND TRUST ON INTENTION TO PAY IN ZISWAF COLLECTION THROUGH DIGITAL PAYMENTS
}

\author{
Fadillah Nur Syafira ${ }^{a}$ \\ Ririn Tri Ratnasarib \\ Shafinar Ismail ${ }^{\mathbf{C}}$ \\ a,b Islamic Economics Department, Faculty of Economics and Business, University of Airlangga \\ c Business Management, Universiti Teknologi Mara (UiTM) \\ Email: Fadillah.nur.syafira-2016@feb.unair.ac.ida; ririnsari@feb.unair.ac.id ${ }^{b}$; \\ shafinar138@gmail.com ${ }^{c}$
}

\begin{tabular}{|c|c|}
\hline ARTICLE HISTORY & ABSTRACT \\
\hline $\begin{array}{l}\text { Received: } \\
12 \text { January } 2020 \\
\text { Revised: } \\
25 \text { May } 2020 \\
\text { Accepted: } \\
25 \text { May } 2020 \\
\text { Online available: } \\
30 \text { June } 2020 \\
\text { Keywords: } \\
\text { Digital Payment, } \\
\text { Intention to Pay, } \\
\text { Religiosity, } \\
\text { Trust, } \\
\text { ZISWAF }\end{array}$ & $\begin{array}{l}\text { The use of digital payment in Indonesia has increased rapidly. The } \\
\text { number of users continues to grow every year, making various zakat } \\
\text { institutions, infaq, sadaqah, and waqf start innovating to raise funds } \\
\text { using a digital payment system. This excellent innovation seems in } \\
\text { contrast with the amount of of zakat funds, infaq, waqf, and alms } \\
\text { collected; it is still far below the potential number of funds. Many } \\
\text { factors influence the intention to pay of the Muslim community in } \\
\text { paying zakat, infaq, endowments, and alms. Some factors that need to } \\
\text { be investigated are religiosity and trust factor. The aim of this research } \\
\text { is to analysis the religiosity and trust factor towards intention to pay } \\
\text { zakat, infaq and endowment. Based on that statement, questionnaires } \\
\text { will be given to } 200 \text { respondents to determine the effect of these } \\
\text { factors on the intention to pay of the Muslim community in paying } \\
\text { zakat, infaq, endowments, and alms. Using mix methods between } \\
\text { quantitative and qualitative, the data is primary from questioner. The } \\
\text { result of this study shows that each religiosity and trust has insignificant } \\
\text { and significant related to the intention to pay zakat, infaq, } \\
\text { endowments, and alms. However, trust as intervening variable could } \\
\text { affect religiosity indirectly, regarding its impact towards intention to } \\
\text { pay. }\end{array}$ \\
\hline
\end{tabular}

\section{INTRODUCTION}

Indonesia is the fourth most populous country in the world (Central Intelligence Agency, 2020) with Islam as the majority of its religion (Ratnasari et al., 2019). Based on data reported by the Pew Research Center (2010), adherents of Islam in Indonesia amounted to 205 million people or 88 percent of the total population. That number represents 13 percent of all Muslims in the world. This fact can certainly be a great potential in the collection of zakat, infaq, alms, and endowments (ziswaf), but the reality is not like that. This is because zakat institutions in Indonesia are very limited, 
which is only Rp1.8 trillion of the Rp300 trillion collected each year (Heikal \& Khaddafi, 2014).

The development of technology that is so fast at this time can be various kinds of facilities in ziswaf payments are very easy to find, one of which is using digital finance or commonly heard as fintech (financial technology). The use of technology tries to see the extent to which businesses utilize technology for production, management, and marketing purposes (Ratnasari et al., 2019). Fintech is a digital technology application that is used as a financial intermediary tool (Aaron et al., 2017). In addition, fintech is also defined as a financial system created by an industry consisting of financial companies, thereby making the delivery of financial services more efficient (World Bank, 2016).

The benefits offered by fintech have even attracted the attention of the Indonesian government. This can be seen from the government's plan to make Indonesia the biggest digital economy player in Southeast Asia in 2020 (Ministry of Communication and Information of the Republic of Indonesia, 2015). Currently, many Indonesian people use fintech in their daily lives so that it can facilitate all activities compared to when not using fintech. In Indonesia, there are currently several platforms that facilitate the public to make payments such as GoPay, OVO, Funds, LinkAja, and PayPal.

The ease of performing zakat, infaq, alms and endowments for Indonesian Muslim communities has also been provided by Bank Indonesia with the electronification of charity boxes through QR codes. At the Indonesia Sharia Economic Festival (Fesyar) in 2019 in Surabaya, Bank Indonesia activated a QR code on a thousand houses of worship in East Java and managed to set a record for the Indonesian World Record Museum (MURI). The public can give infaq, alms, or donations directly by scanning the QR code available at the house of worship. All houses of worship can follow this step by coming to Bank Indonesia.

The formation of an electronic charity box with a QR code can increase transparency and accountability in the management of income and expenses because funds go directly to the account of a place of worship (Bank Indonesia, 2019). There are many benefits of mobile payment such as convenience, transaction speed, security, mass payments, and reducing the use of cash (Verkijika, 2020). In addition, the ongoing digitalization process in the payment industry has increased the inherent complexity of digital platform dynamics (De Reuver et al., 2018). Based on the benefits that can be received from fintech and its rapid development, there should be an increase in the collection of zakat, infaq, alms, and endowment funds in Indonesia. However, apart from factors related to intention to pay, it did not appear to have increased significantly.

For consumers, fintech provides benefits through better services, more choices, and lower prices. For players selling products or services, fintech can simplify the transaction chain, reduce operational costs, and capital costs. On the other hand, 
fintech for a country can provide benefits such as encouraging the transmission of economic policies and increasing the velocity of money so that it encourages economic activities of the people (Bank Indonesia, n.d.). All the benefits offered by fintech should make the intention to pay of the Muslim community for digital ziswaf collection increase. Therefore, research on factors that influence the intention to pay of the Muslim community on collecting zakat, infaq, alms, and digital waqf needs to be done.

Many factors influence the intention to pay of the Muslim community on digital ziswaf collection. In this study, the authors identify religiosity and trust as factors that influence the intention to pay zakat, infaq, almsgiving, and digital waqf of the community digitally. Religion is an important cultural factor to study because it has a significant influence on attitudes, values, and behavior in individuals and society (Putra et al., 2017). Meanwhile, religiosity is an important factor in determining individual behavior. Azman and Bidin (2015) said that Muslims who uphold religious values are expected to be more aware of the obligation to pay zakat, infaq, alms, and endowments compared to Muslims with low religious values. The same thing applies to trusts or trusts that can affect the intention to pay of the Muslim community in fulfilling the obligation of tithing. Bennett and Barkensjo (2005) assert that trust involves trust; the party that is trusted not only fulfills related obligations but must fully satisfy the party that trusts. A trust will be proven when an organization is considered credible, reliable, sincere, and honest. These four things need to be owned by the collection and distribution of zakat, infaq, alms, and endowments so that people feel confident that the assets that have been handed over have been addressed to the right people.

\section{LITERATURE REVIEW}

\section{Religiosity}

The main motivating factor for religious followers to carry out their religious guidance is the factor of faith or religiosity. A person who truly believes is someone who obeys all the commands of Allah, be it easy or difficult, liked or despised, even by killing oneself or leaving his hometown (Nasution, 2017). Robbins et al. (1966) identified five dimensions of a person's religiosity that can be measured to find out whether a person is religious or not which was then elaborated by Ratnasari (2015) in an Islamic context, namely 1 ) the dimension of belief (aqeedah) which explains the extent to which a person accepts dogmatism in religion; 2) dimension of religious practice (sharia) which is a dimension of religious practice, showing the level of frequency or intensity of people when carrying out ritual activities as instructed and encouraged by their religion; 3 ) the dimension of experience (ihsan) is the religious experience encountered by a Muslim while carrying out his religious teachings; 4) dimension of religious knowledge (science), namely the extent to which a person understands the teachings of his religion; and 5) the dimension of practice is the extent 
to which a person's behavior is based on religious teachings in his life (Ratnasari, 2015; Robbins et al., 1966).

Religiosity is a vital factor, considering that religion is one of the supporting factors in the foundation of society. These basic pillars have an important impact on thought processes, characteristics, and behavior at the individual and group levels. Religiosity is the reciprocal attitude of principles and practices in matters that are purified or in routine life and it encourages understanding of the associations and duties of one another when someone lives in a group (Mukhtar \& Butt, 2012). Religiosity can be defined as the extent to which a person is committed to religion and teachings (B. R. Johnson et al., 2001). It has been proven in several studies that people's attitudes, behavior, and character are shaped by their religious beliefs (Barro \& McCleary, 2003; Lehrer, 2004). This is because religious components, elements, and dimensions can determine affective and cognitive functions which ultimately affect one's judgment (Idris et al., 2012).

Although religiosity is recognized as an important factor in understanding human behavior, measurement of religiosity is often a problem in the literature. It has been suggested that measuring religiosity is a complex task and researchers also see religiosity from various perspectives (Abdullah \& Sapiei, 2018; Idris et al., 2012). Therefore, many measurements have been used by researchers to measure religiosity (Abou-Youssef et al., 2015). Palil and Rusyidi (2013) for example, used an individual approach where they measured the level of religiosity according to the number of times the person attended religious activities, whether the person was raised religiously at home and described themselves as religious or non-religious people. Some researchers use religious affiliation and religious commitment to measure religiosity.

\section{Trust}

Mayer et al. (1995) define trust as the willingness of one party to be vulnerable to another party's actions based on the expectation that the other party will take certain actions that are important to the trusting party, regardless of the ability to monitor or control the other party. A. Sargeant and Lee (2004) define trust as the belief that each individual from an organization/sector will never exploit the vulnerability of stakeholders who entrust to the organization by being fair, reliable, competent, and ethical in all transactions. Melendéz (2001) notes that an individual or group will not contribute to the organization and something they do not trust.

Trust plays an important role in the collection of social funds (Shukor et al., 2019). Trust will not only affect recurring donations and increase the number of donations (Burnett, 1992; A. Sargeant \& Lee, 2004), but also believe that funds will be used appropriately by accepting organizations (Ritchie et al., 1999) in supporting legal obligations and organizational morals (Sargeant \& Lee, 2002). Hossain and Dwivedi (2014) in their research on collecting donations using digital payments, emphasized 
that institutions that collect funds must also publish and provide detailed information as well as collect data to increase trust among users. This relates to trust or trust which is a person's certainty that another individual or certain institution will maintain the expected commitment (Luhmann, 2018). Failure to maintain public trust can lead to negative consequences, including decreased donations, damage to reputation, or even the collapse of the organization so that maintaining and developing trust between the community and nonprofit organizations is important to encourage social fundraising activities (de Jager, 2017).

In the field of applied technology, various studies on trust have been carried out. These studies highlight the importance of trust as an instrument to improve relationships with consumers and enhance credibility and perceptions of system security (Cabanillas et al., 2018). Today many consumers depend on online product reviews before deciding to pay for or use a product or service. One example is a google play store or apple store consumer who can evaluate application product reviews to make decisions about the use of technology (von Helversen et al., 2018). There are perceived concerns about security and fraud issues, coupled with low public awareness, trust factors play an important role in the process of adapting to technology (Liébana-Cabanillas et al., 2018).

\section{Intention to Pay}

Ajzen and Fishbein (1980) define intention or intention as cognitive readiness to perform a behavior. Intention is a willingness to try to do something (Ajzen, 1991). Meanwhile, Farouk et al. (2018) added that intention indicates how much effort someone is willing to commit to doing something. Intention plays an important role in the implementation of worship in Islam because worship that is not accompanied by intention will not get a good reward from God (Qardawi, 1988). Intention to products and services is the result of the process of satisfaction felt by an individual of the products and services that have been provided by providers of products and services (Ratnasari et al., 2020). Intention or intention is the extent to which people consciously plan for future behavior (Davis \& Warshaw, 1992) and include decision making to take action (Malle \& Knobe, 1997). Based on some of these definitions, the intention to pay or intention to pay is the willingness or readiness to pay for goods or services to be received (Londoño et al., 2017).

The intention to pay or intention to pay referred to in this study is the payment of zakat, infaq, alms, and endowments on a digital platform. Donations or payments for charity projects are now not only using manual processes but also in electronic form such as online donations. Internet technology has emerged and is increasingly developing, making e-commerce a common practice and evolving donations (Sura et al., 2017). 


\section{Digital Payment System}

Digital payment system or financial technology (fintech) is the combination of financial services with modern technology so that changing business processes from ordinary systems to be more efficient. In addition, the payment process that is usually done face-to-face while carrying a sum of cash or through an ATM can now be done remotely, using a mobile phone wherever we are in seconds. The existence of fintech overcomes the problem of buying and selling transactions, especially for someone who has high mobility who does not have much time to come to shopping, or does not have time to bank and ATM just to transfer funds, on the other hand may also be reluctant to visit the place because of lack of service friendly.

Today's digital payment systems also include services such as wallets that can help customers in various ways, and also provide merchants with a system that is simple, easy to use, and handling. Currently, there are remote payment technologies such as cellphone wallets that need to be installed on smartphones to enable consumers to save money and make transactions directly from wallets via mobile phones (Madan \& Yadav, 2016). Customers will enjoy fast and convenient services and service providers will get customer loyalty with the additional benefit provided in the form of reduced costs in transactions (V. L. Johnson et al., 2018). In Indonesia, there are currently many digital payment service providers with mobile payments such as OVO, DANA, GoPay, LinkAja, and PayPal. By simply scanning the QR Code, the amount of payment to be made will be printed on the cellphone screen and payment can be made immediately.

\section{Collection of Zakat, Infaq, Alms, and Digital Waqf}

Zakat or also referred to as Islamic taxation is an obligation of Muslims who fulfill the zakat requirements to give a certain amount of their wealth to the rightful recipients or asaf which have been determined in the Al-Quran (Wulandari \& Kassim, 2016). The Qur'an specifically states that the following eight categories of recipients or asaf are entitled to receive the allocation of zakat, including the needy, poor, debtors (gharmin), displaced travelers (ibnus sabil), new converts (converts), those who are converted, those who are converted free from slavery (riqab), those who are in the way of Allah (fisabilillah), and those who collect zakat (amil) (Al Jaffri Saad \& Haniffa, 2014). The obligation to pay zakat among Muslims is emphasized in the Qur'an and has been mentioned many times. Those who disregard the obligation of zakat will receive severe punishment on the day on which humans are tried. There are two type of zakat, namely zakat fitrah paid by Muslims in the month of Ramadan and zakat on wealth which includes zakat on work income, business income, savings, crops and agriculture, gold and silver, stocks, and natural resources (Azman \& Bidin, 2015 ).

According to Hamid et al. (2014), the contemporary needs of the community can be met by utilizing infaq as an optimal means to increase wealth. Infaq is seen as an important alternative to improving the economy of Muslim communities to reduce 
poverty. Alms according to Al-Zuhaili (1996) is the gift of property to needy people, people in need, or other parties who are entitled to receive alms without being accompanied by compensation. This alms is sunnah not compulsory. To distinguish infaq from zakat, which is obligatory, the jurists use the term sadaqah tatawwu or alsadaqah al-nafilah while for alms use the term al-sadaqah al-mafrudhah.

Meanwhile, according to Yusof et al. (2014), in waqf there are four pillars involved, namely waqif or representative people; mawquf or property or capital; mauquf 'alaih or beneficiaries be it family members, offspring, the poor, or the community; and sighah or consent (offer) and qabul (acceptance) of waqf. Endowments are permanent, cannot be requested or returned and dispositions outside specific destinations will be prohibited. Yusof et al. (2014) in their research concluded that waqf excute as an magestic social purpose in economic growth by improving the national development plan for poverty alleviation and developing social services. Indonesia as the country with the most Muslim population in the world certainly has great potential in collecting zakat, infaq, alms, and endowments.

Currently, many platforms provide services in payment of zakat, infaq, alms, and waqf based on technology. In addition, many zakat, infaq, alms, and endowments institutions are currently based on websites so that an individual or group only needs to transfer with their digital payment. Examples of such institutions in Indonesia are Rumah Zakat as a philanthropic institution and kitabisa.com which are donation and fundraising sites (fundraising) for online initiatives, campaigns, and social programs (www.kitabisa.com). The page provides zakat, infaq, alms, and endowments distribution services by accepting payments via digital such as OVO, GoPay, Funds, LinkAja, Paypal, and so on. The public can directly scan the QR code listed on the website according to their digital payment service provider.

\section{The Relationship between Religiosity and Intention to Pay}

Religion refers to the structure of beliefs, symbols, and practices that are structured to enable one to feel close to God and as a guide for individual relationships with others (Souiden \& Rani, 2015). Ashraf Ali (2016) states in his research that religion more or less influences the consumption behavior and buying intention of Muslims. In fact, Muslim beliefs and practices have several possible effects on consumer behavior. In addition, Islamic rules and regulations provide judgment and consideration for every aspect of individual and social life (Ashraf Ali, 2016).

Muslims with high religious commitment, obediently obeying religious obligations such as carrying out five daily prayers, fasting throughout the month of Ramadan, performing Sunnah worship such as going to the mosque and reading the Koran, and having morality, it is possible to obey obligations such as paying zakat. Religious factors have a strong influence on perceptions of generosity which simultaneously makes people want to contribute to give cash waqf (Rizal \& Amin, 
2017). In Islam, one's intention to pay zakat as a religious obligation depends very much on the level of belief and commitment to the religion itself (Farouk et al., 2018). Religion influences Muslims' intention to pay, trust, and implementation of worship performed by Muslim consumers has several possible effects on consumer behavior, rules, and orders in Islam providing judgment and consideration for every aspect of a Muslim's individual and social life (Ashraf Ali, 2016).

Allah has ordered His servants to fulfill their obligations as Muslims, one of which is tithing. The order is contained in Surah Al-Baqarah verse 43 which means, "And establish prayer, pay zakat, and ruku'lah with those who bow" (Ministry of Religion of the Republic of Indonesia, 2007).

$\mathrm{H}_{1}$ : Religiosity has a positive effect on the intention to pay of Indonesian people in collecting zakat, infaq, alms, and digital endowments.

\section{Relationship between Religiosity and Trust}

Kayed and Hassan (2011) in their research on Islamic banks, found that compliance with Islamic principles is considered a pillar of customer trust. Religious Muslims will tend to have high trust in banks that claim that they practice Sharia values compared to those who do not. That means religious Muslim consumers believe that the bank has done its job correctly. Alhazmi (2019) also states that a greater emphasis on religion in promoting products can influence trust. Various companies now use religious beliefs as marketing tactics to express positive consumer attitudes by developing consumer confidence in their products and services (Selim et al., 2019).

The discussion shows that the religiosity of a person influences trust positively (Berggren \& Bjørnskov, 2011; Brañas-Garza et al., 2009; Tan \& Vogel, 2008). Muslims who have a relatively high level of religiosity tend to do whatever is ordered by religion without hesitation. This indicates that religious people have a higher level of trust compared to people with a low level of religiosity (Usman, 2017).

$\mathrm{H}_{2}$ : Religiosity has a positive effect on Indonesian people's trust in the collection of zakat, infaq, alms, and digital endowments.

\section{Relationship between Trust and Intention to Pay}

Trust is an important factor for charitable organizations because it can encourage people's willingness to provide financial support to these organizations (Abdul Shukor et al., 2019). Adrian Sargeant and Lee (2002) showed in their research that trust plays a positive role that influences the intention to pay of the alms giver. They found that an increase in trust tended to lead to an increase in intention to pay.

Trust is caused by the behavior of an organization. Organizations that are considered wasteful and inefficient will find it difficult to get financial support. The community hopes that nonprofit organizations can be trusted and work selflessly in 
the public interest and common interests (Moon et al., 2017). The level of trust in nonprofit organizations will increase if the community trusts the nonprofit organization to act according to its function, which is fulfilling social and political obligations in society. The normative and value-oriented nature of organizations makes them more dependent on community trust (Moon et al., 2017). This phenomenon is in accordance with the hadith of the Messenger of Allah which states that goodness will come when honesty is applied, "Let you always be honest, because honesty leads to goodness, and goodness takes someone to heaven. And if someone always acts honest and still chooses to be honest, then it will be noted in Allah's side as an honest person. " (Narrated by Bukhari \& Muslim).

$\mathrm{H}_{3}$ : Trust has a positive effect as an intervening variable between religiosity and intention to pay for the people of Indonesia in collecting zakat, infaq, alms, and digital waqf.

\section{RESEARCH METHODS}

This research uses mixed methods, namely qualitative and quantitative approaches. In a quantitative approach, the type of data used is primary data obtained from distributing questionnaires both offline and online. In total, 200 survey questionnaires were distributed, but the number of eligible questionnaires was 185 questionnaires. The data collection process was conducted from October to November 2019. The questions representing each variable used a Likert scale in measuring respondents' opinions. The description of respondents who chose the value of 1 is strongly disagree, 2 means disagree, 3 means neutral, 4 means agree, and 5 means totally agree has been listed in the questionnaire distributed.

The object of this research is the digital payment with mobile payment which is used by most Indonesian people as payment instruments in collecting zakat, infaq, endowments, and alms as well as zakat, infaq, endowments, and alms institutions that use digital payments in their collection. Various types of mobile payment services are used by Indonesian people such as OVO, GoPay, DANA, and LinkAja in collaboration with several organizations to collect zakat, infaq, endowments, and alms such as Dompet Dhuafa, Kitabisa.com, Rumah Zakat, and BAZNAZ. According to Marginingsih (2019), it is predicted that transactions using mobile payments in Indonesia will reach a very fantastic amount in 2020, which is around 459 trillion rupiahs (Marginingsih et al., 2019). Based on data from Bank Indonesia, digital payment transactions quadrupled in 2018 to Rp 47.2 trillion (bi.go.id).

The independent variable in this study is the level of religiosity and the level of trust of Indonesian people as an intervening variable whose effect is examined by the author of the dependent variable, namely intention to pay on the collection of zakat, infaq, alms, and digital waqf. The population used in this study is the people of Indonesia, especially the citizens of Surabaya. The study was conducted in Indonesia 
because the majority of the population is Muslim (Ratnasari et al., 2019). Sampling using a purposive sampling method on 200 respondents both online and directly with the criteria of respondents: Muslim, aged 21 years or more, have a digital payment account (GoPay, OVO, FUN, LinkAja, PayPal), and have used and know how to use digital payment. Data processed using structural equation model (SEM), Partial Least Square (PLS) was chosen to analyze statistics because of its effectiveness in measuring construct reliability and validity. SmartPLS software was chosen as a tool for data processing.

As for the qualitative approach, focus group discussions (FGDs) are conducted with offline respondents to further explore the answers of respondents. In the FGD a group of participants discussed specific problems and collected information that contained various forms of cognition expressed by the groups involved, such as experiences, perceptions, insights, and opinions (Kraaijvanger et al., 2016).

\section{RESULT AND ANALYSIS}

Based on respondents' answers from questionnaires distributed, a total of 106 respondents with a percentage of $57 \%$ knew or had heard of zakat, infaq, alms, and waqf payments using digital payment, while a number of 79 respondents with a percentage of $43 \%$ never knew or never heard of zakat payments, infaq, endowments, and alms by using digital payment. A total of 45 respondents were male and 140 respondents were female, indicating the percentage of female respondents was $76 \%$ while the percentage of male respondents was $24 \%$. Based on the data obtained by respondents, respondents aged 21-25 years amounted to 179 people with a percentage of $96.5 \%$, respondents aged 26-35 years amounted to 5 people with a percentage of $3 \%$, respondents aged 45-55 years amounted to 1 person with a percentage of $0.5 \%$.

Based on respondents' answers, spending 149 respondents with a percentage of $80.5 \%$ was under 2 million rupiahs a month. A total of 27 respondents with a percentage of $14.6 \%$ spent $2-4$ million rupiah in a month. Respondents with an expenditure of 4-6 million rupiahs a month amounted to 5 respondents with a percentage of $2.8 \%$. Respondents with an expenditure of 6-8 million rupiahs a month are 3 respondents with a percentage of $1.6 \%$ and respondents with expenditures above 8 million in a month are 1 respondent with a percentage of $0.5 \%$. Based on the respondents' answers in the questionnaire distributed, there were 132 respondents with GoPay users with a percentage of 31\%. The respondents who used OVO were 142 respondents with a percentage of $36 \%$. Respondents who used funds amounted to 77 respondents with a percentage of $20 \%$. LinkAja user respondents numbered 47 respondents with a percentage of $12 \%$. Respondents who use PayPal are 5 respondents with a percentage of $1 \%$. 
Table 1

Convergent Validity $(>0,5)$

\begin{tabular}{cc}
\hline Indicator & Loading Factor \\
\hline IP1 & 0.846 \\
IP2 & 0.548 \\
IP3 & 0.854 \\
IP4 & 0.765 \\
IP6 & 0.769 \\
R1 & 0.801 \\
R2 & 0.671 \\
R3 & 0.398 \\
R4 & 0.587 \\
R5 & 0.711 \\
R6 & 0.529 \\
R7 & 0.546 \\
T1 & 0.728 \\
T2 & 0.832 \\
T3 & 0.866 \\
T4 & 0.747 \\
& 0.669 \\
\hline
\end{tabular}

Source: Smart PLS (Processed Data)

From the validity test conducted the first time, it turns out that the religiosity indicator loading factor value is $\mathrm{R} 2$ has a value of 0.398 below the accepted value limit of 0.5 so that the indicator must be discarded so that the data becomes valid. The second validity test is done after removing the indicator variables whose values are below 0.5 . The construct validity value (AVE) of religiosity after the second validity test is 0.402 or is below the accepted construct validity value limit of 0.5 . Finally, the researcher selected the indicator variable again by increasing the loading factor indicator value limit to 0.6 . After conducting the third validity test, because the entire loading factor indicator value of each variable has been raised to a minimum of 0.6 , the construct validity value (AVE) of all variables becomes above the accepted limit of 0.5 so that the validity test results are declared valid.

Table 2

Validity of Constructions (AVE) Second and Third

\begin{tabular}{ccc}
\hline \multirow{2}{*}{ Variable } & \multicolumn{2}{c}{ Average Variance Extracted (AVE) } \\
\cline { 2 - 3 } & $\begin{array}{c}\text { Second } \\
\text { (the loading value of the indicator factor } \\
>0.5)\end{array}$ & $\begin{array}{c}\text { Third } \\
\text { (the loading value of the indicator } \\
\text { factor 0.6) }\end{array}$ \\
\hline Intention To Pay & 0.594 & 0.664 \\
Religiosity & 0.402 & 0.560 \\
Trust & 0.612 & 0.612 \\
\hline
\end{tabular}

Source: Smart PLS (Processed Data) 
Table 3

Discriminant Validity (Cross Loading) $>0.6$ and more dominant than other variables

\begin{tabular}{cccc}
\hline Indicator & Intention To Pay & Religiosity & Trust \\
\hline IP1 & 0.844 & 0.180 & 0.555 \\
IP3 & 0.855 & 0.193 & 0.494 \\
IP4 & 0.767 & 0.249 & 0.450 \\
IP5 & 0.792 & 0.109 & 0.442 \\
IP6 & 0.812 & 0.197 & 0.474 \\
R1 & 0.112 & 0.603 & 0.147 \\
R4 & 0.156 & 0.787 & 0.155 \\
R7 & 0.219 & 0.835 & 0.271 \\
T1 & 0.361 & 0.254 & 0.832 \\
T2 & 0.457 & 0.297 & 0.867 \\
T3 & 0.560 & 0.165 & 0.747 \\
T4 & 0.451 & 0.127 & 0.668 \\
\hline
\end{tabular}

Source: Smart PLS (Processed Data)

Table 4

Reliability

\begin{tabular}{cc}
\multicolumn{2}{c}{ Reliability } \\
\hline Variable & Composite Reliability \\
\hline Intention To Pay & 0.908 \\
Religiosity & 0.790 \\
Trust & 0.862 \\
\hline
\end{tabular}

Source: Smart PLS (Processed Data)

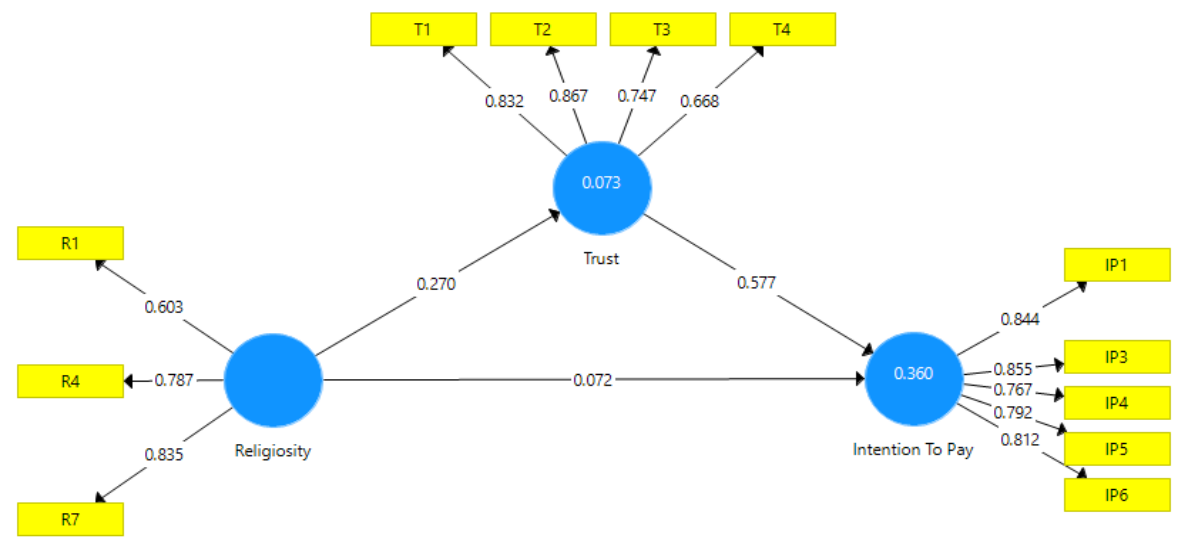

Figure 1. Inner Model

Source: Smart PLS (Processed Data)

Based on the results of research with a quantitative approach, religiosity does not significantly influence people's intention to pay zakat, infaq, alms, and endowments on digital collection, marked by the original sample value of 0.072 . According to research conducted by Suhartanto (2019), intention to become a client of an Islamic bank and recommend banks to others is influenced by the image and trust of the bank, not by factors of religiosity. Whereas based on the results of respondents' answers in a qualitative approach study, namely focus group discussions, some 
respondents argued that the money deposited in a digital payment account would be deposited into the Bank Indonesia minimum statutory reserves where interest would be changed according to economic stability. It shows that transactions using digital payments contain usury so that it will systemically cause inflation. Perception in the context of Islamic economics has certain limitations, the perception of Muslim consumers is born from the teachings of Islam (Ratnasari et al., 2019).

Table 5

$\mathrm{R}$ Square results

\begin{tabular}{ccc}
\hline Variable & R Square & R Square Adjusted \\
\hline Intention To Pay & 0.360 & 0.353 \\
Trust & 0.073 & 0.068 \\
\hline
\end{tabular}

Source: Smart PLS (Processed Data)

Table 6

Direct Hypothesis Test

\begin{tabular}{lccccc}
\hline \multicolumn{1}{c}{ Relationship Between Variables } & $\begin{array}{c}\text { Original } \\
\text { Sample } \\
(\mathbf{O})\end{array}$ & $\begin{array}{c}\text { Sample } \\
\text { Mean } \\
(\mathbf{M})\end{array}$ & $\begin{array}{c}\text { Standard } \\
\text { Deviation } \\
\text { (STDEV) }\end{array}$ & $\begin{array}{c}\text { T Statistics } \\
\text { (|O/STDEV|) }\end{array}$ & $\begin{array}{c}\text { P } \\
\text { Values }\end{array}$ \\
\hline Religiosity -> Intention To Pay & 0.072 & 0.077 & 0.069 & 1.047 & 0.296 \\
Religiosity -> Trust & 0.270 & 0.280 & 0.068 & 3.949 & 0.000 \\
Trust -> Intention To Pay & 0.577 & 0.583 & 0.052 & 11.109 & 0.000 \\
\hline
\end{tabular}

Source: Smart PLS (Processed Data)

Table 7

Indirect Hypothesis Test

\begin{tabular}{lccccc}
\hline $\begin{array}{c}\text { Relationship Between } \\
\text { Variables }\end{array}$ & $\begin{array}{c}\text { Original } \\
\text { Sample (O) }\end{array}$ & $\begin{array}{c}\text { Sample } \\
\text { Mean (M) }\end{array}$ & $\begin{array}{c}\text { Standard } \\
\text { Deviation } \\
\text { (STDEV) }\end{array}$ & $\begin{array}{c}\text { T Statistics } \\
\text { (|O/STDEV|) }\end{array}$ & P Values \\
\hline $\begin{array}{l}\text { Religiosity } \rightarrow \text { Trust } \rightarrow \text { Intention } \\
\text { To Pay }\end{array}$ & 0.156 & 0.164 & 0.046 & 3.407 & 0.001 \\
\hline
\end{tabular}

Source: Smart PLS (Processed)

Based on the findings after the study, religiosity has an effect on trust with an original sample value of 0.270 . That means that the level of religiosity of respondents influences trust in institutions or institutions collecting zakat, infaq, alms, and endowments through digital payments. The higher the level of religiosity of a person, the level of their trust in the institutions of collecting zakat, infaq, endowments, and alms through digital payments is also higher. The findings obtained after conducting the study stated that trust has a significant positive effect on intention to pay with a sample value of 0.577 . This shows that the higher the trust in the collection of zakat, infaq, alms, and digital endowments, the higher the level of desire to pay on the collection of zakat, infaq, alms, and digital endowments. This finding is in line with the findings of Shao et al. (2019) who in his research found that trust in digital payments influences intention to pay and desire to pay using digital payments 


\section{CONCLUSION}

After processing the data and see the results of the analysis and discussion about the effect of religiosity and trust on the intention to pay on the collection of zakat, infaq, alms, and digital waqf, it can be concluded that religiosity does not significantly influence the intention to pay on the collection of zakat, infaq, alms, and digital endowments. Religiosity has a significant positive effect on the trust variable as an intervening variable on the collection of zakat, infaq, alms, and digital waqf. Trust has a significant positive effect on the intention to pay on the collection of zakat, infaq, alms, and digital endowments. That means religiosity does not directly affect intention to pay but can affect intention to pay if the trust variable becomes an intervening variable between religiosity and intention to pay.

Although the findings given from this study contribute to theoretical and practical contributions, some limitations and future research directions need to be discussed. This research only focuses on the influence of religiosity and trust in the intention to pay. Future research can include other factors as variables such as ease of use, altruism, and others. Future studies can also be included in the research questionnaire for more complete data such as experience in usage and others. Because this research approaches a quantitative method that is measured using a Likert scale and a qualitative approach with focus group discussions, future research can also research with qualitative approaches such as in-depth interviews that are deemed necessary so that they can better understand the answers of respondents. In addition, this research only focuses on digital collection so that subsequent studies can compare digital collection and non-digital collection. It aims to explore each of the advantages and disadvantages of the two systems more closely, as well as the views and opinions of respondents regarding both systems.

\section{REFERENCES}

Aaron, M., Rivadeneyra, F., \& Sohal, S. (2017). Fintech: Is this time different? A framework for assessing risks and opportunities for central banks. Bank of Canada Staff Discussion Paper, 10, 1-32. www.bank-banque-canada.ca

Abdul Shukor, S., Johari, F., Abd Wahab, K., Kefeli @ Zulkefli, Z., Ahmad, N., Haji Alias, M., Abdul Rahman, A., Mohd Orip, N. M., Ibrahim, P., \& Abu-Hussin, M. F. (2019). Trust on awqaf institutions: evidence from Malaysia. Journal of Islamic Marketing, 10(2), 511-524. https://doi.org/10.1108/JIMA-05-2017-0054

Abdullah, M., \& Sapiei, N. S. (2018). Do religiosity, gender and educational background influence zakat compliance? The case of Malaysia. International Journal of Social Economics, 45(8), 1250-1264. https://doi.org/10.1108/IJSE-03-2017-0091

Abou-Youssef, M. M. H., Kortam, W., Abou-Aish, E., \& El-Bassiouny, N. (2015). Effects of religiosity on consumer attitudes toward Islamic banking in Egypt. International Journal of Bank Marketing, 33(6), 786-807. https://doi.org/10.1108/IJBM-022015-0024

Ajzen, I, \& Fishbein, M. (1980). Understanding attitudes and predicting social behaviour. Pretince Hall. http://www.citeulike.org/group/38/article/235626 
Ajzen, Icek. (1991). The theory of planned behavior. Organizational Behavior and Human Decision Process, 50(2), 179-211.

Al-Zuhaili, W. (1996). al-Fiqhu al-Islam wa Adillatuhu Juz II. Dar alFikr.

Al Jaffri Saad, R., \& Haniffa, R. (2014). Determinants of zakah (Islamic tax) compliance behavior. Journal of Islamic Accounting and Business Research, 5(2), 182-193. https://doi.org/10.1108/JIABR-10-2012-0068

Alhazmi, B. M. (2019). Religiosity and customer trust in financial services marketing relationships. Journal of Financial Services Marketing, 24(1-2), 31-43. https://doi.org/10.1057/s41264-019-00062-9

Ashraf Ali, K. (2016). Impact of Religiosity on Buying Behavior of Financial Products: A Literature Review. International Journal of Finance and Banking Research, 2(1), 18. https://doi.org/10.11648/j.ijfbr.20160201.14

Azman, F. M. N., \& Bidin, Z. (2015). Factors influencing zakat compliance behavior on saving. International Journal of Business and Social Research, 05(01), 118-128.

Bank Indonesia. (n.d.). Edukasi: Financial Technology. https://www.bi.go.id/id/edukasi-perlindungan-konsumen/edukasi/produk-danjasa-sp/fintech/Pages/default.aspx

Barro, R. J., \& McCleary, R. M. (2003). Religion and economic growth across countries. American Sociological Review, 68(5), 760-781. https://doi.org/10.2307/1519761

Bennett, R., \& Barkensjo, A. (2005). Relationship quality, relationship marketing, and client perceptions of the levels of service quality of charitable organisations. International Journal of Service Industry Management, 16(1), 81-106. https://doi.org/10.1108/09564230510587168

Berggren, N., \& Bjørnskov, C. (2011). Is the importance of religion in daily life related to social trust? Cross-country and cross-state comparisons. Journal of Economic Behavior and Organization, 80(3), 459-480. https://doi.org/10.1016/j.jebo.2011.05.002

Brañas-Garza, P., Rossi, M., \& Zaclicever, D. (2009). Individual's religiosity enhances trust: Latin american evidence for the puzzle. Journal of Money, Credit and Banking, 41(2-3), 555-566. https://doi.org/10.1111/j.1538-4616.2009.00222.x

Burnett, K. (1992). Relationship fundraising. In A Donor-Based Approach to the ... (2nd ed., Vol. $12, \quad$ Issue 2 ). Jossey-Bass. http://samples.sainsburysebooks.co.uk/9780787966812_sample_385619.pdf

Central Intelligence Agency. (2020). The World Fact Book. https://www.cia.gov/library/publications/resources/the-worldfactbook/geos/ni.html

Davis, F. D., \& Warshaw, P. R. (1992). What do intention scales measure? Journal of General Psychology, 119(4), 391-407. https://doi.org/10.1080/00221309.1992.9921181

de Jager, C. E. (2017). A Question of Trust: the Pursuit of Consumer Trust in the Financial Sector by Means of EU Legislation. Journal of Consumer Policy, 40(1), 25-49. https://doi.org/10.1007/s10603-016-9334-8

De Reuver, M., Sørensen, C., \& Basole, R. C. (2018). The digital platform: A research agenda. Journal of Information Technology, 33(2), 124-135. https://doi.org/10.1057/s41265-016-0033-3

Departemen Agama RI. (2007). Al-Qur'an dan Terjemahnya. Syaamil Cipta Media. 
Farouk, A. U., Md Idris, K., \& Saad, R. A. J. Bin. (2018). Moderating role of religiosity on Zakat compliance behavior in Nigeria. International Journal of Islamic and Middle Eastern Finance and Management, 11(3), 357-373. https://doi.org/10.1108/IMEFM-05-2017-0122

Hamid, M. A., Suhaili, N. A., Palil, M. R., \& Janor, H. (2014). Waqaf Perkongsian Strategik sebagai Pendekatan Wakaf Pendidikan Tinggi. Pelestarian Waqaf Pendidikan Tinggi : Memperkasa Pendidikan Tinggi Negara, 455-472.

Heikal, M., \& Khaddafi, M. (2014). The Intention to Pay Zakat Commercial: An Application of Revised Theory of Planned Behavior. Journal of Economics and Behavioral Studies, 6(9), 727-734. https://doi.org/10.22610/jebs.v6i9.532

Hossain, M. A., \& Dwivedi, Y. K. (2014). What improves citizens' privacy perceptions toward RFID technology? A cross-country investigation using mixed method approach. International Journal of Information Management, 34(6), 711-719. https://doi.org/10.1016/j.ijinfomgt.2014.07.002

Idris, K. M., Bidin, Z., \& Saad, R. A. J. (2012). Islamic religiosity measurement and its relationship with business income zakat compliance behavior. Jurnal Pengurusan, 34, 3-10. https://doi.org/10.17576/pengurusan-2012-34-01

Johnson, B. R., Jang, S. J., Larson, D. B., \& De Li, S. (2001). Does adolescent religious commitment matter? A reexamination of the effects of religiosity on delinquency. Journal of Research in Crime and Delinquency, 38(1), 22-44. https://doi.org/10.1177/0022427801038001002

Johnson, V. L., Kiser, A., Washington, R., \& Torres, R. (2018). Limitations to the rapid adoption of M-payment services: Understanding the impact of privacy risk on $\mathrm{M}$ Payment services. Computers in Human Behavior, 79, 111-122. https://doi.org/10.1016/j.chb.2017.10.035

Kayed, R. N., \& Hassan, M. K. (2011). The global financial crisis and Islamic finance. Thunderbird International Business Review, 53(5), 551-564. https://doi.org/10.1002/tie.20434

Kementrian Komunikasi dan Informasi Republik Indonesia. (2015). Indonesia Akan Jadi Pemain Ekonomi Digital Terbesar di Asia Tenggara. https://kominfo.go.id/index.php/content/detail/6441/Indonesia\%2BAkan\%2BJa di\%2BPemain\%2BEkonomi\%2BDigital\%2BTerbesar\%2Bdi\%2BAsia\%2BTenggara/ $0 /$ berita_satker

Kraaijvanger, R., Almekinders, C. J. M., \& Veldkamp, A. (2016). Identifying crop productivity constraints and opportunities using focus group discussions: A case study with farmers from Tigray. NJAS - Wageningen Journal of Life Sciences, 78, 139-151. https://doi.org/10.1016/j.njas.2016.05.007

Lehrer, E. L. (2004). Religion as a determinant of economic and demographic behavior in the United States. Population and Development Review, 30(4), 707-726. https://doi.org/10.1111/j.1728-4457.2004.00038.x

Liébana-Cabanillas, F., Muñoz-Leiva, F., \& Sánchez-Fernández, J. (2018). A global approach to the analysis of user behavior in mobile payment systems in the new electronic environment. Service Business, 12(1), 25-64. https://doi.org/10.1007/s11628-017-0336-7

Londoño, B., Prado, Y., \& Salazar, V. (2017). Service quality, perceived value, satisfaction and intention to pay. Academia Revista Latinoamericana de Administración, 30(2), 269-286. https://doi.org/10.1108/arla-01-2016-0022 
Luhmann, N. (2018). Trust and Power. John Willey and Sons.

Madan, K., \& Yadav, R. (2016). Behavioural intention to adopt mobile wallet: a developing country perspective. Journal of Indian Business Research, 8(3), 227244. https://doi.org/10.1108/JIBR-10-2015-0112

Malle, B. F., \& Knobe, J. (1997). The folk concept of intentionality. Journal of Experimental Social Psychology, 33(2), 101-121. https://doi.org/10.1006/jesp.1996.1314

Mayer, R. C., Schoorman, F. D., \& Davis, J. H. (1995). An integrative model of organizational trust: Past, present, and future. Academy of Management Review, 20(3), 709-734.

Melendéz, S. E. (2001). The nonprofit sector and accountability. New Directions for Philanthropic Fundraising, 31, 121-132. https://doi.org/10.1002/pf.3107

Moon, S. G., Jeong, S. Y., \& Choi, Y. (2017). Moderating effects of trust on environmentally significant behavior in Korea. Sustainability (Switzerland), 9(3), 415. https://doi.org/10.3390/su9030415

Mukhtar, A., \& Butt, M. M. (2012). Intention to choose Halal products: The role of religiosity. Journal of Islamic Marketing, 3(2), 108-120. https://doi.org/10.1108/17590831211232519

Nasution, J. (2017). Analisis Pengaruh Kepatuhan Membayar Zakat Terhadap Keberkahan. At-Tawassuth, II(2), 282-303.

Palil, M. R., \& Rusyidi, M. A. (2013). The Perception of Tax Payers on Tax Knowledge and Tax Education with Level of Tax Compliance: A Study the Influences of Religiosity. ASEAN Journal of Economics, Management and Accounting, 1(1), 118129.

Pew Research Center. (2010). Muslim Population Indonesia. https://www.pewforum.org/2010/11/04/muslim-population-of-indonesia/

Putra, M. I., Ratnasari, R. T., \& Prasetyo, A. (2017). Religiosity Effect Analysis of Consumer Behavior and Consumer Intention on Online Shopping: East Java Community Case Study. Academic Research International, 8(4), 103-110.

Qardawi, Y. (1988). Zakah Law.

Ratnasari, R. T. (2015). Religiosity on Shopping Orientation and Behavioral Intention For Moslem and Non-Moslem Costumers. 6th Global Islamic Marketing Conference. www.E-Journal.unair.ac.id

Ratnasari, R. T., Gunawan, S., Possumah, B. T., Rusmita, S. A., Widiastuti, T., \& Herianingrum, S. (2019). Halal food certification for improving the competitiveness of small and medium enterprises. Opcion, 35(Special Issue 22), 510-525.

Ratnasari, R. T., Gunawan, S., Septiarini, D. F., Rusmita, S. A., \& Kirana, K. C. (2020). Customer satisfaction between perceptions of environment destination brand and behavioural intention. International Journal of Innovation, Creativity and Change, 10(12), 472-487.

Ritchie, R. J. B., Swami, S., \& Weinberg, C. B. (1999). A brand new world for nonprofits. International Journal of Nonprofit and Voluntary Sector Marketing, 4(1), $26-42$. https://doi.org/10.1002/nvsm.54

Rizal, H., \& Amin, H. (2017). Perceived ihsan, Islamic egalitarianism and Islamic religiosity towards charitable giving of cash waqf. Journal of Islamic Marketing, 
8(4), 669-685. https://doi.org/10.1108/JIMA-05-2015-0037

Robbins, R., Glock, C. Y., \& Stark, R. (1966). Religion and Society in Tension. In Sociological Analysis (Vol. 27, Issue 3). Rand McNally. https://doi.org/10.2307/3710391

Sargeant, A., \& Lee, S. (2004). Donor trust and relationship commitment in the UK charity sector: the impact on behavior. Nonprofit and Voluntary Sector Quarterly, 33(2).

Sargeant, Adrian, \& Lee, S. (2002). Improving public trust in the voluntary sector: an empirical analysis. Donor Trust and Relationship Commitment in the UK Charity Sector: The Impact on Behavior, 33(2), 185-202.

Selim, N. I. I. B., Zailani, S., Aziz, A. A., \& Rahman, M. K. (2019). Halal logistic services, trust and satisfaction amongst Malaysian 3PL service providers. Journal of Islamic Marketing. https://doi.org/10.1108/JIMA-05-2018-0088

Shao, Z., Zhang, L., Li, X., \& Guo, Y. (2019). Antecedents of trust and continuance intention in mobile payment platforms: The moderating effect of gender. Electronic Commerce Research and Applications, 33. https://doi.org/10.1016/j.elerap.2018.100823

Souiden, N., \& Rani, M. (2015). Consumer attitudes and purchase intentions toward Islamic banks: The influence of religiosity. International Journal of Bank Marketing, 33(2), 143-161. https://doi.org/10.1108/IJBM-10-2013-0115

Suhartanto, D. (2019). Predicting behavioural intention toward Islamic bank: a multigroup analysis approach. Journal of Islamic Marketing, 10(4), 1091-1103. https://doi.org/10.1108/JIMA-02-2018-0041

Sura, S., Ahn, J., \& Lee, O. (2017). Factors influencing intention to donate via social network site (SNS): From Asian's perspective. Telematics and Informatics, 34(1), 164-176. https://doi.org/10.1016/j.tele.2016.04.007

Tan, J. H. W., \& Vogel, C. (2008). Religion and trust: An experimental study. Journal of Economic Psychology, 29(6), 832-848. https://doi.org/10.1016/j.joep.2008.03.002

Verkijika, S. F. (2020). An affective response model for understanding the acceptance of mobile payment systems. Electronic Commerce Research and Applications, 39. https://doi.org/10.1016/j.elerap.2019.100905

von Helversen, B., Abramczuk, K., Kopeć, W., \& Nielek, R. (2018). Influence of consumer reviews on online purchasing decisions in older and younger adults. Decision Support Systems, 113, 1-10. https://doi.org/10.1016/j.dss.2018.05.006

Wulandari, P., \& Kassim, S. (2016). Issues and challenges in financing the poor: case of Baitul Maal Wa Tamwil in Indonesia. International Journal of Bank Marketing, 34(2), 216-234. https://doi.org/10.1108/IJBM-01-2015-0007

Yusof, M. F. M., Hasarudin, M. H., \& Romlin, N. (2014). Cash Waqf and Infaq: a Proposed E-Philanthropy in Malaysia. Jurnal Kemanusiaan, 12(1), 1-10. 